\title{
PENGARUH PROGRAM SERTIFIKASI TANAH TERHADAP AKSES PERMODALAN BAGI USAHA MIKRO DAN KECIL STUDI KASUS PROGRAM SERTIFIKASI TAHUN 2008 DI KABUPATEN KULON PROGO
}

\author{
Istikomah \\ Direktorat Pendaftaran Hak Tanah dan Guna Ruang \\ Badan Pertanahan Nasional Republik Indonesia \\ Email: nafisfaustazaki@yahoo.co.id
}

\begin{abstract}
This paper discusses influence of land certification program on Micro and Small Enterprises (MSEs) to access capital through the identification of factors that influence the decision of micro and small entrepreneurs (MSEs) in the use of Certificate of Land Ownership (SHM) as collateral and identification of the influence of certificate program to increase total loans granted to MSEs as the land owner. The identification of the factors that influence the decision of MSEs in the use of SHM as loan collateral $\left(\mathrm{Y}_{1}\right)$, use binary logit regression analysis with independent variable including credit application purposes $\left(X_{1}\right)$, the suitability of the number of credits earned by the required amount $\left(X_{2}\right)$, the preception of lending procedures financial institutions $\left(X_{3}\right)$, perceptions of ability to repay the loan $\left(X_{4}\right)$, the age of the respondent $\left(X_{5}\right)$, sex $(X 6)$, the education level of respondents $\left(X_{7}\right)$, MSEs participation in MSE land certificate program $\left(X_{8}\right)$ and the amount of labor $\left(X_{9}\right)$. Meanwhile, the identification of the factors that affect the increase in lending financial in the factors that affect the increase in lending financial institution $\left(Y_{2}\right)$ uses multiple linear regression analysis with the independent variables include omzet $\left(X_{1}\right)$, the use of certificates as collateral $\left(X_{2}\right)$, MSEs perception of the analysis applied to financial institutions $\left(X_{3}\right)$, the age of respondents $\left(X_{4}\right)$, sex $\left(X_{5}\right)$, educational level $\left(X_{6}\right)$, and participation in the program MSEs land certificate $\operatorname{MSE}\left(\mathrm{X}_{7}\right)$.
\end{abstract}

Keywords: Certification for MSEs, Capital access, Collateral

\begin{abstract}
ABSTRAK
Makalah ini membahas Pengaruh Program Sertifikasi Tanah Usaha Mikro dan Kecil (UMK) terhadap akses permodalan melalui identifikasi faktor-faktor yang mempengaruhi keputusan pengusaha mikro dan kecil (PMK) dalam memanfaatkan Sertifikat Hak Milik atas Tanah (SHM) sebagai agunan ( $\left.\mathrm{Y}_{1}\right)$ dan identifikasi pengaruh program sertipikasi terhadap kenaikan jumlah pinjaman $\left(\mathrm{Y}_{2}\right)$.Identifikasi faktor-faktor yang mempengaruhi keputusan PMK dalam memanfaatkan SHM sebagai agunan $\left(Y_{1}\right)$ menggunakan analisis regresi binary logit dengan variabel bebas meliputi keinginan pengembangan usaha $\left(X_{1}\right)$, kesesuaian jumlah kredit yang diperoleh dengan jumlah yang dibutuhkan $\left(X_{2}\right)$, persepsi prosedur peminjaman lembaga keuangan $\left(X_{3}\right)$, persepsi kemampuan membayar pinjaman $\left(X_{4}\right)$, umur $\left(X_{5}\right)$, jenis kelamin $\left(X_{6}\right)$, tingkat pendidikan $\left(X_{7}\right)$, Keikutsertaan PMK dalam program sertifikasi tanah UMK $\left(X_{8}\right)$ dan jumlah tenaga kerja $\left(X_{9}\right)$. Dalam mengidentifikasi faktor-faktor yang mempengaruhi kenaikan pinjaman dari lembaga keuangan $\left(Y_{2}\right)$ menggunakan analisis regresi linear berganda dengan variabel bebasnya meliputi omzet usaha $\left(X_{1}\right)$, penggunaan sertifikat sebagai agunan $\left(X_{2}\right)$, persepsi PMK terhadap analisis yang diterapkan lembaga keuangan $\left(X_{3}\right)$, umur $\left(X_{4}\right)$, jenis kelamin $\left(X_{5}\right)$, tingkat pendidikan $\left(X_{6}\right)$, dan keikutsertaan PMK dalam program sertifikasi tanah UMK $\left(X_{7}\right)$.
\end{abstract}

Kata Kunci: Sertifikasi UMK, akses permodalan, agunan 


\section{Istikomah -- Pengaruh Program Sertifikasi Tanah Terhadap Akses Permodalan bagi Usaha Mikro dan Kecil (Studi Kasus Program Sertifikasi Tahun 2008 Di Kabupaten Kulon Progo)}

\section{PENGANTAR}

Sektor UMKM merupakan komponen terbesar dalam struktur usaha di Indonesia dan keberadaannya menjangkau hampir seluruh wilayah Indonesia. Pada saat krisis melanda perekonomian Indonesia tahun 1997, UMKM tetap bertahan dan bahkan jumlahnya meningkat dengan pesat. UMKM terbukti tahan terhadap krisis dan mampu survive sebagai berikut: pertama, tidak memiliki utang luar negeri; kedua, tidak banyak utang ke perbankan karena diangap unbankable; ketiga, menggunakan input lokal; keempat, berorientasi ekspor (Kuncoro, 2009).

Data Kementerian Koperasi dan UKM (2010) diketahui bahwa pada tahun 2009 jumlah total UMK di Indonesia mencapai 52,723 juta unit usaha atau sekitar 99,91 persen dari total perusahaan yang ada dengan penyerapan tenaga kerja sebesar 93,533 juta orang (94,59 persen). Hal ini menunjukkan peranan UMK sangat penting sebagai sentra perekonomian dan penyerap tenaga kerja di Indonesia terutama angkatan kerja yang tidak terserap dalam dunia kerja.

Masalah dasar yang dihadapi UMKM sebagai berikut: Pertama, kelemahan dalam memperoleh peluang pasar dan memperbesar pangsa pasar; Kedua, kelemahan dalam struktur permodalan dan keterbatasan untuk memperoleh jalur terhadap sumbersumber permodalan; Ketiga, kelemahan di bidang organisasi dan manajemen sumber daya manusia; Keempat, keterbatasan jaringan usaha kerjasama antar pengusaha kecil (sistem informasi pemasaran); Kelima, iklim usaha yang kurang kondusif, karena persaingan yang saling mematikan; Keenam, pembinaan yang dilakukan masih kurang terpadu dan kurangnya kepercayaan serta kepedulian masyarakat terhadap usaha kecil (Kuncoro, 2009).

Permasalahan UMKM tersebut juga dialamioleh pelakuUMKdiKabupatenKulon Progo. UMKM di Kabupaten Kulon Progo merupakan sektor industri yang menyerap tenaga kerja terbanyak dan merupakan pendukung perekonomian terbesar di Kabupaten Kulon Progo, terutama UMKM yang bergerak dalam sektor pertanian, peternakan, kehutanan dan perikanan (Dinas Koperasi dan UMKM Kabupaten Kulon Progo tahun 2011 dalam BPS, 2012). Potensi besar UMKM tersebut tidak berarti bebas dari berbagai permasalahan dalam pengembangannya. Salah satu permasalahan utama UMKM di Kabupaten Kulon Progo adalah aksesibilitas UMKM terhadap kredit yang masih sangat rendah. Struktur modal meskipun sudah hampir seimbang, tetapi jumlah kredit yang dibutuhkan masih lebih besar daripada realisasi pinjaman yang disetujui oleh perbankan (Ridwan, 2010).

Akses UMK terhadap lembaga keuangan yang masih rendah bermula dari buruknya sistem kepemilikan aset. Hal ini disebabkan oleh ketidaktahuan masyarakat tentang aset yang dimilikinya (Soto, 2006). Persoalan lain yang membuat para pengusaha ekstralegal terperangkap dalam kemiskinan adalah hambatan dalam memanfaatkan aset yang ada. Tanah, rumah, dan tempat kegiatan usaha yang dimiliki tidak dilengkapi dokumen resmi, sehingga aset-aset ini tidak dapat dijadikan agunan untuk mendapatkan kredit sehingga disebut modal mati (Amir, 2008).

Soto (2006) menekankan pentingnya pencatatan atau sertifikasi tanah, dengan asumsi setelah tanah terdata secara resmi dan sah, pemilik dapat menjadikannya sebagai modal hidup, misalnya untuk agunan kredit bank. Hak kepemilikan tanah yang dinyatakan dalam Sertifikat (Titles) adalah produk kegiatan pendaftaran tanah (land register), yaitu kegiatan pemberian jaminan kepastian kepemilikan atas tanah atau property right. Kegiatan ini dilakukan pemerintah sebagai sarana perlindungan hukum bagi pemegang hak atas tanah sebagaimana diatur dalam Undang-undang Pokok Agraria Nomor 5 Tahun 1960 atau disebut juga kegiatan penetapan aspek legalitas kepemilikan tanah (Amir, 2008).

Sertifikat Hak Milik Atas Tanah (SHM) merupakan salah satu jaminan yang dapat diterima bank karena dianggap memenuhi persyaratan yuridis maupun ekonomis. 
Tanah-tanah Pengusaha Mikro dan Kecil (PMK) pada umumnya belum bersertifikat, sehingga tidak dapat digunakan untuk jaminan kredit pada perbankan (Hulu, 2000). Kalaupun dapat diagunkan, jumlah kredit yang diperoleh kecil karena pihak perbankan memperhitungkan resiko yang tinggi dari agunannya sehingga berdampak pada ketidakmampuan UMK untuk menumbuhkan usahanya (Sidipurwanty, 2008).

Upaya peningkatan akses PMK terhadap sumber-sumber permodalan baik perbankan atau lembaga keuangan dan peningkatan kapasitas penyediaan agunan kredit secara mandiri, Badan Pertanahan Nasional Republik lndonesia (BPN Rl) bekerjasama dengan Kementerian Negara Koperasi dan UKM menyelenggarakan program sertifikasi tanah milik PMK. Manfaat langsung bagi penerima program adalah jaminan kepastian hukum hak atas tanah dan perlindungan hukum bagi pemilik tanah, adanya kepastian penguasaan, pemilikan, penggunaan serta pemanfaatan tanah sesuai tujuan yang ingin dicapai dalam penguatan hak, pendaftaran tanah di Indonesia, dan memperoleh serta meningkatkan akses permodalan melalui penggunaan sertifikat sebagai agunan/ jaminan kredit perbankan/lembaga keuangan.

Setiap perusahaan bertujuan untuk mengubah input menjadi output. Input atau faktor produksi "diminta" karena dibutuhkan dalam proses produksi. Proses produksi dilakukan karena adanya permintaan akan output yang dihasilkan. Permintaan akan input timbul karena adanya permintaan akan output atau disebut permintaan turunan (derived demand). Jumlah input yang diminta tergantung pada jumlah yang direncanakan untuk diproduksi. Output yang direncanakan untuk diproduksi tergantung pada perhitungan mengenai tingkat output mana yang diharapkan menghasilkan keuntungan maksimal (Boediono, 2008).

Sumber permodalan bagi UMK merupakan faktor yang sangat penting dalam mendapatkan input atau faktor produksi dalam proses produksi. Menurut Jhigan (2003) pembentukan modal atau capital formation, adalah penentu utama pertumbuhan ekonomi dan lingkaran setan kemiskinan umumnya di negara terbelakang dapat digunting melalui pembentukan modal (Amir, 2008).

Keinginan pelaku usaha dalam mengembangkan usaha biasanya diperlukan tambahan modal kerja. Dengan modal yang memadai akan memudahkan pengusaha untuk mengembangkan usahanya menjadi lebih besar. Umumnya tujuan permintaan modal kerja bagi usaha kecil adalah: (1) untuk mendapatkan profit margin yang lebih baik dan pemasok menghendaki pembayaran secara tunai; (2) adanya peningkatan permintaan/penjualan; (3) ingin mendapatkan tingkat bunga yang lebih rendah; (4) kontinuitas pengadaan bahan baku/barang dagangan di pasar tidak stabil (musiman); (5) adanya perubahan peraturan pemerintah, misalnya devaluasi, inflasi, proteksi terhadap dagangan tertentu, kebijaksanaan ekspor impor bahan baku; (6) adanya kenaikan harga bahan baku dan biaya-biaya operasional; dan (7) untuk meningkatkan efisiensi biaya (Suhardjono, 2003 dan Jumhur, 2006).

Tambahan modal kerja yang diperlukan pelaku usaha tersebut dapat diperoleh dari pinjaman atau kredit. Undang-Undang Nomor 10 Tahun 1998 tentang perubahan UU Nomor 7 tahun 1992, pasal 1 ayat 11, kredit adalah penyediaan uang atau tagihan yang dapat dipersamakan dengan itu berdasarkan tujuan atau kesepakatan pinjam-meminjam antara bank dengan pihak lain yang mewajibkan pihak peminjam untuk melunasi hutangnya setelah jangka waktu tertentu dengan pemberian bunga.

Kasmir (2003) kredit dapat digolongkan diantaranya berdasarkan.

1. Segi kegunaan kredit.

a. Kredit investasi

Merupakan kredit yang digunakan untuk keperluan perluasan usaha atau membangun pabrik baru di mana masa pemakaian untuk suatu 
periode yang relatif lebih lama dan biasanya digunakan untuk kegiatan utama suatu perusahaan.

b. Kredit modal kerja

Kredit modal kerja adalah kredit yang dipergunakan untuk membiayai kebutuhan modal kerja suatu perusahaan yang pada umumnya berjangka waktu pendek, maksimal satu tahun. Modal kerja merupakan sejumlah dana yang dipergunakan untuk membiayai operasional dari suatu perusahaan. Biaya operasional tersebut mulai dari biaya pengadaan bahan baku/ biaya bahan penolong/biaya bahan setengah jadi, membiayai tenaga kerja dan biaya overhead, proses produksi barang sampai dengan barang tersebut dijual (Suhardjono, 2003 dan Jumhur, 2006).

2. Dilihat dari segi tujuan kredit.

a. Kredit produktif

Merupakan kredit yang digunakan untuk peningkatan usaha atau produksi atau investasi. Kredit ini diberikan untuk menghasilkan barang atau jasa.

b. Kredit konsumtif

Merupakan kredit yang digunakan untuk konsumsi atau dipakai secara pribadi, tidak ada pertambahan barang dan jasa yang dihasilkan.

c. Kredit perdagangan

Merupakan kredit yang digunakan untuk kegiatan perdagangan.

Persepsi PMK terhadap prosedur peminjaman. Hasil penelitian kerjasama Kementerian KUKM dengan BPS (2003) menginformasikan bahwa salah satu kesulitan usaha yang dialami UKM adalah dalam hal permodalan yaitu mencapai 51,09 persen, di mana dalam mengatasi kesulitan permodalan tersebut sebanyak 17,50 persen UKM menambah modalnya dengan meminjam ke bank, sisanya 82,50 persen tidak melakukan pinjaman ke bank tetapi ke lembaga non bank seperti Koperasi Simpan Pinjam (KSP), perorangan, keluarga, dan modal ventura lainnya. Alasan utama yang dikemukakan UKM kenapa mereka tidak meminjam ke bank adalah: (1) prosedur sulit (30,30 persen); (2) tidak berminat (25,34 persen); (3) tidak punya agunan $(19,28$ persen); (4) tidak tahu prosedur (14,33 persen); (5) suku bunga tinggi (8,82 persen); dan (6) proposal ditolak (1,93 persen) (Sulaeman, 2004).

Persepsi kemampuan membayar dari PMK. Keputusan seorang pelaku usaha dalam mengajukan pinjaman didasarkan pada berbagai pertimbangan, baik pertimbangan mikro maupun makro serta tidak tertutup kemungkinan untuk mempertimbangkan keduanya agar mampu memberikan analisis yang jauh lebih kuat. Bagi perusahaan sangat penting untuk menghindari timbulnya risiko dikemudian hari. Perusahaan yang membutuhkan danauntuk membiayai proyek jangka panjang sebaiknya mengambil dana dari sumber jangka panjang dan sebaliknya. Hal ini bertujuan untuk: (1) memperlancar angsuran pembayaran agar selalu tepat waktu dan tidak terlambat; (2) mampu terus melaksanakan pengerjaan proyek sehingga tidak mengalami kendala dan berbagai permasalahan; (3) menghindari black list perbankan karena terlambat membayar atau tidak mampu melunasi (Fahmi dan Hadi, 2010).

Aspek kemampuan membayar debitur merupakan pertimbangan utama karena bank mengharapkan kredit yang diberikan dapat berjalan lancar dan tidak berhenti di tengah jalan. Bank menilai kemampuan debitur dengan melihat pola konsumsi debitur melalui mutasi rekening, sehingga bank dapat melihat besaran pendapatan dan pengeluaran debitur. Bank juga akan mengecek histori kredit dan status kredit debitur melalui pusat data Bank Indonesia. Aspek kemampuan membayar (capacity of repayment) dari UMK ini tidak bisa dilepaskan dari aspek yang lain yaitu aspek karakter, kapasitas dan modal. UMK umumnya merupakan perusahaan keluarga yang 
cenderung belum memisahkan administrasi keuangan keluarga dengan keuangan perusahaan. Hal ini menyebabkan kesulitan bagi perbankan untuk mengetahui seberapa jauh dan seberapa besar kemampuan membayar dari UMK.

Tenaga kerja merupakan salah satu faktor sumber daya yang dibutuhkan dalam menghasilkan barang dan jasa disamping tanah dan modal termasuk mesin-mesin, peralatan, bahan mentah, tenaga listrik, kemajuan teknologi dan lainlain. SDM memegang peranan utama dalam meningkatkan produktivitas karena alat produksi dan teknologi pada hakekatnya adalah hasil karya manusia. Produktivitas tenaga kerja menjadi pusat perhatian, disamping produktivitas tanah dan modal.

Keikutsertaan pada program sertipikasi tanah UMK. Masih rendahnya akses ke sumber-sumber permodalan bagi UMK disebabkan karena faktor pemilikan agunan (collateral), kemampuan UMKM untuk memberikan agunan masih rendah, baik dikarenakan terbatasnya pemilikan aset berharga dan atau kurangnya legalitas aset yang dimiliki. Pengembangan akses UMKM terhadap sumber-sumber perkreditan formal terutama perbankan merupakan salah satu alternatif untuk memperkokoh basis pembangunan UMKM agar kemampuan akses UMKM tersebut dapat diwujudkan, maka diperlukan perencanaan yang komprehensif serta kesiapan termasuk strategi yang akan dilakukan dan penyediaan sumber daya. Salah satu strategi untuk meningkatkan akses UMKM terhadap pinjaman kredit dari bank komersial telah dibangun oleh pemerintah melalui beberapa jenis program penguatan antara lain program modal awal dan padanan, program sertipikasi tanah, program resi gudang dan yang terakhir adalah program penjaminan oleh pemerintah melalui program Kredit Usaha Rakyat (KUR). Program-program tersebut pada hakikatnya bertujuan untuk memperkuat posisi UMKM dalam berhadapan dengan bank-bank komersial, dengan cara mengeliminir kelemahan
UMKM dari aspek agunan (collateral) (Subandi, 2007).

Usia mempunyai kaitan dengan tingkat kedewasaan psikologis. Semakin lanjut usia seseorang dan diharapkan semakin mampu menunjukkan kematangan jiwa, dalam arti semakin bijaksana, semakin mampu berpikir rasional, semakin mampu mengendalikan emosi, semakin toleran terhadap pandangan dan perilaku yang berbeda dari perilaku sendiri, semakin mampu mengendalikan emosi dan sifat-sifat lain yang menunjukkan kematangan intelektual dan psikologis itu (Siagian, 1995 dan Pasaribu, 2007).

Ciri khas perkembangan karier sebagai berikut: (1) usia dewasa awal (18 tahun sampai 40 tahun), sangat terkait dengan tugas perkembangan dalam hal membentuk keluarga dan pekerjaan (Hurlock, 1991). Ketika seseorang masuk dalam masa dewasa awal memiliki tugas pokok untuk memilih bidang pekerjaan yang cocok dalam bakat, minat, dan faktor psikologisnya. Masih banyak orang dewasa muda yang bingung dengan pilihan kariernya, situasi seperti ini juga terjadi dalam wirausaha. Masa dewasa awal itu merupakan masa coba-coba untuk berkarier. Itulah sebabnya usia berpengaruh pada tinggi rendahnya prestasi kerja; (2) usia dewasa madya (usia 40 tahun sampai 60 tahun), bercirikan keberhasilan dalam pekerjaan. Prestasi puncak pada usia ini juga berlaku bagi wirausaha; (3) usia dewasa akhir (usia di atas 60 tahun), orang mulai mengurangi kegiatan karier atau berhenti sama sekali, menikmati jerih payahnya selama bekerja dan mencurahkan perhatian pada kehidupan spiritual, dan sosial (Hutagalung dan Situmorang, 2008).

Tingkat pendidikan berpengaruh pada pola pikir seseorang, cara pandang seseorang dalam melihat suatu permasalahan, dan dalam bertindak. Pendidikan merupakan sarana mengembangkan sumber daya manusia guna meningkatkan kemampuan intelektual, meningkatkan ketrampilan, meningkatkan produktivitas kerja, serta meningkatkan pendapatan, dan taraf hidup. Sumber daya manusia merupakan titik sentral yang 
sangat penting untuk maju dan berkembang. Sebagian besar usaha kecil tumbuh secara tradisional. Sumber daya manusia UMK sebagian besar memiliki keterbatasan baik dari segi pendidikan formal maupun dari segi pengetahuan dan ketrampilan (Panggabean, 2002). Keadaan ini menyebabkan motivasi berwirausaha menjadi tidak cukup kuat untuk meningkatkan usaha dan meraih peluang pasar. Dengan keterbatasan pendidikan tersebut, pada umumnya manajemen usaha dikelola dengan cara yang sederhana oleh keluarga, sehingga pengusaha kurang mampu mengadministrasikan usahanya. UMK biasanya bersifat turun temurun dan hanya memenuhi kebutuhan keluarga, sehingga PMK kurang mempunyai kelembagaan yang kuat dan hanya mampu memperkerjakan tenaga kerja yang berasal dari keluarga (Mesman, 2008).

Perkembangan usaha kecil menengah ditentukanolehsejumlahfaktor, salahsatunya adalah tingkat pendidikan pengusaha. Pendidikan merupakan salah satu unsur yang dapat merubah sikap dan perilaku, meningkatkan dan mengembangkan pola pikir, wawasan serta memudahkan pengusaha menyerap informasi yang sifatnya membawa pembaharuan dan kemajuan bagi usahanya. Pendidikan merupakan suatu proses pengembangan pengertian yang meliputi pengembangan mental dan ketrampilan yang digunakan oleh seseorang dalam memecahkan masalah secara efektif. Pendidikan memiliki keterkaitan yang sangat erat dengan proses belajar yang merupakan proses perubahan struktur kognitif. Apabila seorang belajar maka akan bertambah pengetahuannya (Noersasongko, 2005).

Place dan Adholla (1998) melakukan penelitian terhadap dampak ekonomi pendaftaran tanah pada petani kecil di Kenya. Dampak pendaftaran tanah dan pemberian hak atas tanah untuk keamanan penguasaan tanah, penggunaan kredit formal, hasil panen, dan konsentrasi tanah dianalisis dari data area dan rumah tangga di 4 lokasi di Kenya. Hasilnya mengindikasikan bahwa program pendaftaran dan pemberian hak atas tanah memiliki pengaruh yang lemah terhadap kesadaran petani akan hak-hak atas tanahnya, pemanfaatan kredit dan jangka waktu, hasil panen, atau konsentrasi pengusahaan tanah. Kesimpulan dari penelitian ini bahwa hak atas tanah dibutuhkan untuk meningkatkan keamanan dari hak-hak tersebut daripada meningkatkan produksi pertanian. Keterbatasan modal yang dimiliki pemerintah, sasaran terbaik yang dapat dilakukan dengan menyediakan infrastruktur yang lebih baik, dan menciptakan kesempatan pasar yang seharusnya juga menguasai permintaan yang lebih besar untuk pemberian hak atas tanah.

Penelitian yang dilakukan Byamugisha (1999) telah membuktikan hubungan positif antara pendaftaran tanah/sertifikasi tanah dengan peningkatan akses kredit di pedesaan Thailand. Dengan meningkatnya akses terhadap kredit, para petani Thailand mampu meningkatkan nilai investasinya terhadap tanah dengan peningkatan modal pertanian dari kredit tersebut yang pada gilirannya meningkatkan produksi pertanian dan pendapatan para petani tersebut. Hal yang sama terjadi di Philippines, Indonesia, Honduras, Brazil, Peru, Costa Rica, Brazil, Honduras, Jamaica, Ghana, Costa Rica, Brazil, Ecuador and Paraguay.

Pengaruh Program Sertifikasi Masal di Kota Cimahi bertujuan untuk melihat dampak program sertifikasi masal terhadap meningkatnya pinjaman atau penyerapan modal dalam mendukung pengembangan UKM. Sasaran yang ingin dicapai dalam penelitian tersebut sebagai beriku: (1) teridentifikasinya jumlah peserta program yang memanfaatkan sertifikat untuk meminjam; (2) besaran nilai penjaman dan pemanfaatan pinjaman; dan (3) teridentifikasinya karakteristik peserta yang memanfaatkan sertifikat untuk meminjam dan yang tidak meminjam serta alasan-alasannya (Abdullatief, 2005 dalam Amir, 2008).

Program sertifikasi masal di Kota Cimahi belum memberikan pengaruhnya terhadap peningkatan jumlah pendaftaran hak tanggungan. Dari 2.977 bidang hasil program sertifikasi masal sporadis (SMS) 
dan Prona, hanya 6 (enam) bidang saja yang terdaftar sebagai obyek Hak Tanggungan atau terdaftar sebagai agunan. Hasil survei lapangan memberikan kesimpulan bahwa program sertifikasi masal di Kota Cimahi belum memberikan dampak yang berarti bagi peningkatan pinjaman atau penyerapan modal oleh UKM.

Dampak Program Sertifikasi Tanah Terhadap Akses Kredit Perbankan dan Peningkatan Pendapatan Petani di Kabupaten Bekasi. Analisis dilakukan terhadap faktor-faktor yang mempengaruhi petani dalam mensertifikatkan tanah, faktorfaktor yang mempengaruhi keputusan petani dalam memanfaatkan SHM sebagai agunan dan pengaruh sertifikasi terhadap peningkatan pendapatan petani. Faktorfaktor yang mempengaruhi keputusan petani mensertifikatkan tanahnya adalah kepentingan sertifikat, prosedur pengurusan, waktu pengurusan sertifikat, biaya pengurusan sertifikat, dan akses informasi pengurusan sertifikat (Amir, 2008).

Faktor-faktor yang mempengaruhi keputusan petani memanfaatkan SHM sebagai jaminan kredit adalah luas tanah, keberadaan sertifikat, jumlah kredit yang diterima, prosedur peminjaman kredit perbankan dan sistem pembayaran kredit perbankan. Faktor prosedur peminjaman dan persepsi tentang kredit macet sehingga tanah disita merupakan penghambat yang perlu mendapat perhatian, karena hal ini menyebabkan keputusan masyarakat memanfaatkan SHM sebagai agunan sangat rendah. Program Sertifikasi Tanah Sistematik tidak serta merta dapat meningkatkan pendapatan petani. Program Sertifikasi Tanah sistematik akan memberi pengaruh nyata terhadap peningkatan pendapatan petani selaku pemilik tanah bila SHM dimanfaatkan sebagai jaminan kredit perbankan (Amir, 2008).

Di Kecamatan Kalibawang Kabupaten Kulon Progo tepatnya di Koperasi Mulia yang berada di Kelurahan Banjaroya, yang menjadi tempat pelaksanaan program sertifikasi tanah UMK tahun 2008 dengan target sertifikasi 100 bidang tanah.
Penentuan lokasi ditentukan oleh Tim Pokja dari Dinas Koperasi dan UKM Kabupaten Kulon Progo dan umumnya terkelompok dalam kecamatan, untuk memudahkan dalam pendataan subjek dan objek tanah dan pengukuran bidang-bidang tanah. Penyebaran peserta sertifikasi tanah-tanah UMK sebagian besar berada di Kelurahan Banjaroya, berdasarkan pertimbangan masih banyak pelaku usaha yang bergerak dalam bidang usaha mikro, rumah tangga, dan belum memiliki sertifikat.

Populasi dalam penelitian ini adalah seluruh PMK yang tergabung dalam Koperasi Mulia yang terletak di Desa Banjaroya baik yang mengikuti program sertipikasi tanah UMKmaupunyangtidakmengikuti program. Sampel diperoleh dari populasi sasaran tersebut. Pengambilan sampel dilakukan dengan random sampling baik untuk PMK yang mengikuti program sertifikasi tanah maupun yang tidak mengikuti program sertifikasi tanah. Metode pengumpulan data digunakan meliputi: (1) Wawancara yakni proses memperoleh keterangan untuk tujuan penelitian dengan cara tanya jawab sambil bertatap muka. Teknik wawancara dilakukan dengan bantuan pedoman daftar pertanyaan. (2) Kuesioner yaitu daftar pertanyaan memperoleh informasi dari UMK di Kecamatan Kalibawang Kabupaten Kulon Progo. (3) Observasi merupakan teknik pengumpulan data menggunakan pengamatan secara langsung serta mencatat data yang diperlukan secara sistematis. Pertama, data primer dikumpulkan dari hasil kuesioner meliputi data keinginan pengembangan usaha, kesesuaian jumlah kredit yang diperoleh, persepsi tentang prosedur peminjaman, persepsi kemampuan membayar pinjaman, umur, jenis kelamin, serta tingkat pendidikan yang diperkirakan berpengaruh terhadap keputusan PMK dalam mengagunkan serifikat ke bank. Selain itu data tentang omzet, penggunaan sertipikat sebagai jaminan, persepsi PMK terhadap analisis kredit yang diterapkan lembaga keuangan, umur, jenis kelamin, tingkat pendidikan dan keikutsertaan 
dalam program sertipikasi diperkirakan berpengaruh terhadap kenaikan jumlah pinjaman yang diberikan lembaga keuangan. Kedua, Data sekunder merupakan data pelengkap yang diperoleh dari instansi yang terkait dengan penelitian yang dilakukan.

Variabel dependen dalam penelitian ini ada dua sebagai berikut: Pertama, keputusan PMK dalam memanfaatkan SHM sebagai agunan/jaminan kredit $\left(Y_{1}\right)$ dengan variabel independenmeliputikeinginan pengembangan usaha, kesesuaian jumlah pinjaman, persepsi PMK terhadap prosedur peminjaman, persepsi PMK terhadap kemampuan membayar kredit, umur, jenis kelamin, tingkat pendidikan, keikutsertaan dalam program sertifikasi tanah, dan jumlah tenaga kerja.

Kedua, Kenaikan jumlah pinjaman yang diberikan lembaga keuangan kepada PMK selaku pemilik tanah $\left(Y_{2}\right)$, dengan variabel independen meliputi kenaikan omzet, penggunaan sertifikat, persepsi PMK terhadap analisis yang diterapkan lembaga keuangan, umur, jenis kelamin, tingkat pendidikan, dan keikutsertaan dalam program sertifkasi tanah.

Alat pendukung analisi menggunakan Regresi Binary Logit digunakan untuk mengidentifikasi faktor-faktor yang mempengaruhi keputusan PMK dalam memanfaatkan SHM sebagai agunan $\left(Y_{1}\right)$. Model umum persamaan regresi logitnya sebagai berikut:

$$
\operatorname{Ln}\left(\frac{P i}{(1-P i)}\right)=\begin{gathered}
\alpha+\beta_{1} X_{1}+\beta_{2} X_{2}+\beta_{3} X_{3}+\beta_{4} X_{4}+\beta_{5} X_{5}+ \\
\beta_{6} D_{1}+\beta_{7} X_{6}+\beta_{8} D_{2}+\beta_{9} X_{7}+€_{i}
\end{gathered}
$$

Keterangan:

$$
\begin{aligned}
\mathrm{a}= & \text { konstanta; } \\
\beta_{1,2,}= & \text { koefisien regresi untuk variabel } \\
& \mathrm{X}_{1,2, \ldots} ; \\
€_{\mathrm{i}}= & \text { error terms; } \\
\mathrm{Pi}= & \text { jikakeputusanPMKmemanfaatkan } \\
& \text { SHM sebagai agunan }=1 ; \\
(1-\mathrm{Pi})= & \text { jika keputusan PMK tidak } \\
& \text { memanfaatkan SHM agunan }=0 ; \\
\mathrm{X}_{1,2, \ldots}= & \text { variabel-variabel independent, } \\
& \text { meliputi. } \\
\mathrm{X} 1= & \text { keinginan pengembangan usaha; }
\end{aligned}
$$

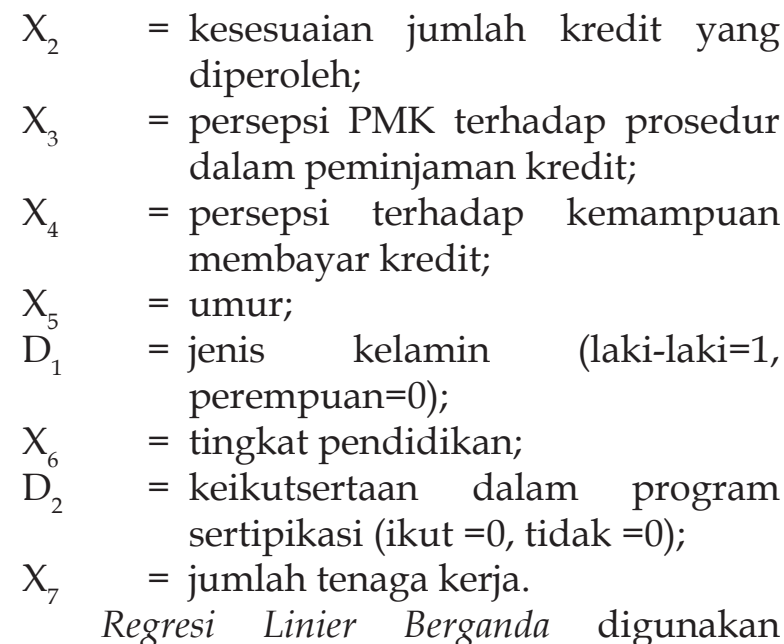
untuk mengidentifikasi faktor-faktor yang mempengaruhi kenaikan jumlah pinjaman yang diberikan lembaga keuangan $\left(Y_{2}\right)$. Persamaan regresinya sebagai berikut.

$Y=\alpha+\beta_{1} X_{1}+\beta_{2} D_{1}+\beta_{3} X_{2}+\beta_{4} D_{2}+\beta_{5} X_{3}+\beta_{6} D_{3}+\beta_{7} X_{4}+\epsilon_{i}$ Di mana:

$\mathrm{Y}=$ variabel dependent $=$ kenaikan jumlah pinjaman;

a $\quad=$ konstanta;

$\beta_{1,2}=$ koefisien regresi untuk variabel $\mathrm{X}_{1,2, \ldots}$;

$\mathrm{X}_{1} \quad=$ kenaikan omzet;

$\mathrm{D}_{1} \quad=$ penggunaan sertipikat (diagunkan $=1$, tidak diagunkan $=0$ );

$\mathrm{X}_{2}=$ persepsi $\mathrm{PMK}$ terhadap analisis kredit yang diterapkan bank;

$\mathrm{D}_{2}=$ keikutsertaan dalam program sertipikasi (ikut $=1$, tidak ikut $=0$ );

$\mathrm{X}_{3} \quad$ = umur;

$\mathrm{D}_{3} \quad=$ jenis kelamin (laki-laki=1, perempuan $=0$ );

$\mathrm{X}_{4} \quad=$ tingkat pendidikan;

$€_{\mathrm{i}}=$ disturbance error/error term (faktor kesalahan).

\section{PEMBAHASAN}

Analisis Regresi Binary Logit (Keputusan PMK memanfaatkan SHM sebagai aguanan $/ Y_{1}$ )

Hasil analisis data uji $\mathrm{z}$ yang menunjukkan signifikansi variabel bebas secara parsial untuk Keputusa PMK memanfaatkan SHM sebagai agunan $\left(Y_{1}\right)$ ditunjukkan pada table berikut. 
Tabel 1. Hasil Analisis Regresi Logit Faktor-faktor yang Mempengaruhi Keputusan PMK dalam Memanfaatkan SHM sebagai Agunan $\left(Y_{1}\right)$

\begin{tabular}{|l|l|l|l|l|}
\hline No & \multicolumn{1}{|c|}{ Variabel } & \multicolumn{1}{c|}{ Koefisien } & Prob (p-value) & \multicolumn{1}{|c|}{ Keterangan } \\
\hline 1 & Konstanta & $-39,706$ & 0,0000 & Signifikan \\
\hline 2 & Keinginan pengembangan usaha $\left(\mathrm{X}_{1}\right)$ & 0,481 & 0,0022 & Signifikan \\
\hline 3 & Kesesuaian jumlah kredit $\left(\mathrm{X}_{2}\right)$ & 0,735 & 0,0341 & Signifikan \\
\hline 4 & Prosedur peminjaman $\left(\mathrm{X}_{3}\right)$ & $-0,337$ & 0,0222 & Signifikan \\
\hline 5 & Kemampuan membayar $\left(\mathrm{X}_{4}\right)$ & 0,613 & 0,0001 & Signifikan \\
\hline 6 & Umur $\left(\mathrm{X}_{5}\right)$ & 0,064 & 0,1523 & Tidak signifikan \\
\hline 7 & Jenis kelamin $\left(\mathrm{D}_{1}\right)$ & $-1,969$ & 0,2075 & Tidak signifikan \\
\hline 8 & Tingkat pendidikan $\left(\mathrm{X}_{6}\right)$ & 0,431 & 0,4670 & Tidak signifikan \\
\hline 9 & Keikutsertaan progam $\left(\mathrm{D}_{2}\right)$ & 0,148 & 0,8742 & Tidak signifikan \\
\hline 10 & Jumlah tenaga kerja $\left(\mathrm{X}_{7}\right)$ & $-0,128$ & 0,7366 & Tidak signifikan \\
\hline
\end{tabular}
Sumber: data primer (diolah).

Pengujian tersebut menggunakan tingkat signifikansi dengan hipotesis sebagai berikut.

$$
\begin{aligned}
\mathrm{H}_{0}: & \begin{array}{l}
\text { Variabel bebas secara individual } \\
\text { tidak mempengaruhi variabel } \\
\\
\text { terikat. }
\end{array} \\
\mathrm{H}_{\mathrm{a}} \quad: & \text { Variabel bebas secara individual } \\
& \text { mempengaruhi variabel terikat. }
\end{aligned}
$$

Ketentuan dalam menolak atau menerima $\mathrm{H}_{0}$ ditentukan menggunakan probabilita $\mathrm{z}$ hitung ( $p$-value) masing-masing variabel bebas dengan tingkat siginifikansi (a). Dalam penelitian ini menggunakan a 5

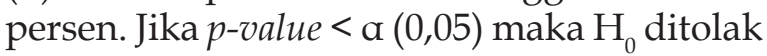
dan menerima $\mathrm{H}_{\mathrm{a}}$ dan sebaliknya jika $p$-value $>\mathrm{a}(0,05) \mathrm{maka}_{0} \mathrm{~d}_{0}$ diterima dan menolak $\mathrm{H}_{\mathrm{a}}$. Persamaan regresi logitnya sebagai berikut:

$$
\begin{aligned}
\operatorname{Ln}\left(\frac{P i}{(1-P i)}\right)= & -39,706+0,481 X_{1}+0,735 X_{2}- \\
& 0,337 X_{3}+0,613 X_{4}+0,064 X_{5}- \\
& 1,969 D_{1}+0,431 X_{6}+0,148 D_{2}- \\
& 0,128 X_{7}+€_{i}
\end{aligned}
$$

Atau :

$$
\begin{aligned}
& \frac{P i}{(1-P i)}=\mathrm{e}^{\mathrm{z}}=\mathrm{e}^{\left(-39,706+0,592 \mathrm{x}_{1}+0,735 \mathrm{x}_{2}+0,337 \mathrm{X}_{3}+0,613 \mathrm{X}_{4}+0,064 \mathrm{X}_{5}-\right.} \\
& =\mathrm{e}^{-39,706} \mathrm{e}^{0,481 \mathrm{X}_{1}} \mathrm{e}^{0,735 \mathrm{X}_{2}} \mathrm{e}^{-0,337 \mathrm{X}_{3}} \mathrm{e}^{0,613 \mathrm{X}_{4}} \mathrm{e}^{0,064 \mathrm{X}_{5}} \\
& \mathrm{e}^{-1,969 \mathrm{D}_{1}} \mathrm{e}^{0,431 \mathrm{x}_{6}} \mathrm{e}^{0,148 \mathrm{D}_{2}} \mathrm{e}^{-0,128 \mathrm{x}_{7}}
\end{aligned}
$$

Dalam tabel di atas diketahui bahwa keinginan pengembangan usaha $\left(X_{1}\right)$ mempunyai nilai $\rho=0,0022$ yang lebih rendah dari a (5 persen) dengan koefisien regresi bertanda positif sebesar 0,481 sehingga hipotesis diterima. Keinginan PMK untuk mengembangkan usaha signifikan berpengaruh positif terhadap keputusan PMK dalam memanfaatkan SHM sebagai jaminan kredit.

Nilai koefisien regresi logit sulit diintrepretasikan langsung. Untuk mengintrepretasikan maka kita melakukan antilog koefisien regresi logit tersebut atau pangkat eksponensial koefisien logit. Nilai tersebut merupakan odds ratio probabilitas kejadian sukses $(p=1)$ dengan kejadian tidak sukses (1-p). Hasil perhitungan odds ratio dari koefisien regresi variabel keinginan pengembangan usaha diperoleh nilai 1,618 (pendekatan dari $\left.(\mathrm{e}=2,718)^{0,481}\right)$. Hal ini dapat diartikan bahwa jika tujuan dalam pengembangan usaha meningkat satu satuan, maka rasio probabilitas memanfaatkan SHM sebagai agunan dengan tidak memanfaatkan SHM sebagai jaminan kredit akan naik dengan faktor 1,618 dengan asumsi variabel bebas yang lain tetap (Winarno, 2010).

Keinginan untuk mengembangkan usaha memotivasi PMK untuk mengagunkan SHM sebagai jaminan, di mana pinjaman yang diperoleh digunakan sebagai modal kerja dalam aktivitas usahanya sehingga diharapkan usahanya dapat berkembang yang 
pada akhirnya dapat menunjang peningkatan pendapatan keluarga. Produsen akan mencari input (modal) jika input-input tersebut akan menghasilkan output dan laba (Arsyad, 1999).

Hal ini didukung dengan data tujuan peserta program sertifikasi tanah UMK dalam mensertipikatkan tanahnya, di mana alasan untuk mengajukan kredit menjadi tujuan kedua setelah tujuan utama memperoleh kepastian hukum atas kepemilikan tanahnya (memperoleh sertifikat), di samping memperoleh rasa aman guna menghindari sengketa. Responden yang bertujuan memperoleh kemudahan dalam meminjam kredit hanya 30,56 persen, sebanyak 63,89 persen bertujuan untuk memperoleh kepastian hukum kepemilikan tanah, mendapatkan rasa aman sebesar 5,56 persen dan bertujuan agar mudah dijual 0 persen.

Kesesuaian jumlah kredit yang diperoleh dengan jumlah kebutuhan $\left(X_{2}\right)$ secara signifikan berpengaruh positif terhadap keputusan PMK dalam memanfaatkan SHM sebagai jaminan kredit. Hal ini menunjukkan bahwa kesesuaian jumlah kredit yang diberikan lembaga keuangan (koperasi) dengan jumlah yang dibutuhkan PMK untuk menutupi kebutuhannya, menjadi salah satu dasar pertimbangan PMK dalam memutuskan untuk memanfaatkan SHM sebagai agunan kredit. Hal ini didasarkan asumsi bahwa jumlah tambahan modal yang diperoleh PMK dari lembaga keuangan (koperasi) cukup dan sesuai dengan kebutuhan yang diperlukan terutama kebutuhan dalam pengembangan usahanya.

Prosedur peminjaman pada lembaga keuangan $\left(X_{3}\right)$ secara signifikan berpengaruh terhadap probabilitas keputusan PMK dalam memanfaatkan SHM sebagai jaminan kredit dengan arah hubungan negatif. Semakin mudah prosedur peminjaman, menurunkan probabilitas keputusan PMK untuk memanfaatkan SHM sebagai agunan. Pada daerah penelitian, Koperasi Mulia sebagai lembaga keuangan mikro menerapkan prosedur peminjaman yang mudah, tidak berbelit-belit dan tidak mengharuskan agunan berupa sertifikat tanah mengingat masih banyak anggota yang tidak memiliki tanah yang bersertifikat. Hal ini memungkinkan beberapa PMK yang membutuhkan dana tidak terlalu besar akan mengajukan pinjaman dengan menggunakan agunan selain sertifikat yang tentunya nilainya sebanding dan sesuai ketentuan untuk menjadi agunan, di antaranya menggunakan BPKB motor, tanaman keras yang sudah berumur dan bernilai tinggi (pohon jati, pohon durian, dan lain-lain), bahkan ada yang menggunakan ternak sapi atau kambing sebagai agunan. Hal inilah yang menyebabkan prosedur peminjaman berkorelasi negatif dengan keputusan PMK memanfaatkan SHM sebagai agunan.

Umumnya prosedur peminjaman merupakan salah satu faktor negatif PMK dalam mengajukan pinjaman ke bank/ lembagakeuangan.Halinisenadadenganhasil penelitian kerjasama Kementerian KUKM dengan BPS (2003) yang menginformasikan alasan utama dikemukakan oleh UKM alasan tidak meminjam ke bank sebagai berikut: (1) prosedur sulit (30,30 persen); (2) tidak berminat (25,34 persen); (3) tidak punya agunan (19,28 persen); (4) tidak tahu prosedur (14,33 persen); (5) suku bunga tinggi (8,82 persen); dan (6) proposal ditolak (1,93 persen) (Sulaeman, 2004).

Persepsi kemampuan membayar pinjaman PMK $\left(X_{4}\right)$ secara signifikan berpengaruh positif terhadap keputusan PMK memanfaatkan SHM sebagai agunan. Dengan nilai koefisien regresi 0,613 (bertanda positif), nilai odds ratio sebesar 1,846 . Hal ini berarti bahwa semakin tinggi persepsi PMK terhadap kemampuan dalam pembayaran pinjaman ke lembaga keuangan, rasio probabilitas PMK dalam memanfaatkan SHM sebagai jaminan kredit dengan tidak memanfaatkan SHM sebagai jaminan kredit akan naik dengan faktor 1,846, dengan asumsi variabel bebas yang lain dianggap konstan. Hal ini berpengaruh terhadap psikologis, dengan persepsi kemampuan membayar yang tinggi, mereka yakin dan optimis bahwa dengan tambahan modal dari kredit tersebut usaha mereka akan berjalan 
dengan lancar dan lebih maju, sehingga ketakutan akan kegagalan dalam usahanya dan tanah yang menjadi agunan kelak akan disita rendah.

Persepsi kemampuan membayar PMK yang rendah menyebabkan kecenderungan PMK dalam memanfaatkan SHM sebagai jaminan kredit akan turun. Persepsi masyarakat bahwa jika tidak dapat membayar kredit atau terjadi kredit macet, maka tanah yang dijaminkan akan disita oleh pihak bank (memberi pengaruh sebesar 99,61 persen) akibatnya masyarakat enggan menjadikan SHM sebagai jaminan kredit ke bank (Amir, 2008).

Keikutsertaan PMK pada program sertifikasi tanah tidak signifikan berpengaruh terhadapkeputusanPMKdalammemanfaatkan SHM sebagai agunan. Keikutsertaan dalam program sertifikat tanah pada lokasi penelitian ini tidak menjadi dasar keputusan mereka dalam memanfaatkan SHM sebagai agunan, tetapi lebih didasarkan pada pertimbangan lain yaitu keinginan pengembangan usaha, kesesuaian jumlah kredit yang diperoleh dengan besarnya kebutuhan, persepsi prosedur peminjaman, dan persepsi kemampuan dalam membayar kredit.

Keikutsertaan PMK dalam program sertifikat tidak signifikan terhadap keputusan dalam memanfaatkan SHM sebagai agunan disebabkan tujuan utama PMK mengikuti program sertifikasi adalah untuk memperoleh kepastian hukum kepemilikan tanah (sebesar 63,89 persen), sedangkan tujuan untuk menjadikannya sebagai agunan kredit masih rendah hanya 30,56 persen (tabel 3.5). Alasan mengapa masyarakat tidak memanfaatkan sertifikatnya sebagai jaminan sebagai berikut: (1) karena tujuan utama mengikuti kegiatan pensertipikatan tanah hanya untuk mendapatkan kepastian hukum kepemilikan tanahnya saja, (2) ketakutan mengalami kredit macet karena tidak dapat mengembalikan hutang, (3) belum memiliki rencana kegiatan usaha (Abdullatief, 2005 dan Amir, 2008).

Tabel 2 (dua) dapat diketahui bahwa peserta program sertifikat yang sudah memanfaatkan SHM sebagai agunan sudah cukup tinggi (sebesar 66,67 persen), hanya 33,33 persen yang belum memanfaatkan. Peserta yang tidak mengagunkan tersebut ternyata 33,33 persen tetap mengajukan pinjaman tetapi menggunakan agunan lain, yaitu berupa ternak/kayu sebesar 75 persen dan menggunakan BPKB sebesar 25 persen. Koperasi Mulia sebagai lembaga keuangan mikro memang memberikan kemudahan prosedur peminjaman. Koperasi Mulia tidak mengharuskan agunan berupa sertifikat tanah untuk jumlah pinjaman yang tidak terlalu besar. Agunan dapat berupa ternak (sapi/kambing) atau agunan berupa pohon jati/kayu jati untuk jumlah pinjaman sekitar 5 juta, bahkan untuk pinjaman maksimal 1 juta tanpa agunan dengan kriteria benarbenar nasabah yang sudah dipercaya pihak koperasi. Umumnya jumlah pinjaman dari PMK di Koperasi Mulia masih tergolong rendah, sekitar 5 jutaan atau 10 jutaan.

Kemudahan prosedur yang diberikan pihak Koperasi Mulia ini memang sesuai dengan prinsip dasar koperasi yang memang bertujuan untuk melayani anggotanya agar bisa berkembang dan bisa lebih sejahtera dan bukan dibentuk untuk mengejar keuntungan atau laba bagi perusahaan koperasi itu sendiri. Faktor kemudahan prosedur yang diberikan Koperasi Mulia ini menjadi salah satu penyebab alasan keikutsertaan PMK dalam program sertifikasi tidak signifikan terhadap keputusan memanfaatkan SHM sebagai agunan. Berikut distribusi penggunaan SHM hasil sertifikasi tanah UMK.

Tabel 2. Distribusi penggunaan SHM hasil program sertifikasi tanah UMK

\begin{tabular}{|l|l|l|}
\hline \multicolumn{1}{|c|}{ Jumlah } & \multicolumn{1}{|c|}{ Prosentase (\%) } \\
\hline Tidak mengagunkan SHM : & 12 & 33,33 \\
\hline 1.tidak pinjam & 8 & 66,67 \\
2. pinjam & 4 & 33.34 \\
\hline
\end{tabular}




\begin{tabular}{|l|l|l|}
\hline 1. agunan ternak/kayu & 3 & 75,00 \\
\hline 2. agunan BPKB & 1 & 25,00 \\
\hline Mengagunkan SHM : & 24 & 66.67 \\
\hline a. sebelumnya belum pernah pinjam & 8 & 33,33 \\
\hline b. pernah pinjam : & 16 & 66,67 \\
\hline 1. agunan ternak/kayu & 5 & 31,25 \\
\hline 2. BPKB & 7 & 43,75 \\
\hline 3. SK Dukuh & 1 & 6,25 \\
4. Tanpa agunan/kepercayaan & 1 & 6,25 \\
\hline 5. Letter C & 1 & 6.25 \\
\hline total & 36 & 100.00 \\
\hline Sumber: data primer (diolah) &
\end{tabular}

Faktor lain yang mungkin menjadi penyebab adalah faktor psikologis dari pelaku usaha mikro dan kecil tersebut. Faktor psikologis yang dimaksud adalah rasa ketakutan dalam diri PMK kalau usahanya tidak berhasil sehingga tidak akan mampu melunasi pinjaman dan takut tanahnya akan disita, bahkan hal tersebut mempunyai pengaruh sangat besar yaitu 99,61 persen, mengakibatkan masyarakat enggan menjadikan SHM sebagai jaminan kredit ke bank. Rasa ketakutan ini disebabkan oleh kepercayaan diri PMK atas kemampuan mereka dalam menjalankan usaha masih rendah. Hal ini secara tidak langsung dipengaruhi oleh tidak adanya atau belum maksimalnya pembinaanpembinaan terhadap PMK tersebut baik pembinaan mengenai manajemen usaha maupun motivasi dalam pengembangan usaha. Pembinaan yang dilakukan baru terbatas pada saat tahap awal pelaksanaan penyuluhan sertifikasi dan pada saat penyerahan sertipikat setelah program sertipikasi selesai (Amir, 2008).

Faktor umur juga berpengaruh dalam rendahnya keputusan PMK dalam pemanfaatan SHM sebagai agunan. Peserta program sertipikasi pada penelitian ini didominasi kelompok umur 60 tahun keatas dan umur 50 tahun keatas. Pada usia tersebut pada umumnya motivasi dan kemampuan dalam pengembangan usaha sudah jauh menurun. Berdasarkan hasil observasi lapangan dan hasil wawancara, dalam menjalankan usaha mereka cenderung bertujuan untuk mempertahankan hidup atau untuk mengisi waktu luang karena sebagian besar anak-anak mereka sudah berkeluarga dan sudah mempunyai cucu, sehingga tinggal menikmati hari tua serta lebih mendekatkan pada kehidupan sosial dan keagamaan. Hal ini menyebabkan keikutsertaan PMK dalam program sertifikasi tidak signifikan mempengaruhi keputusan mereka dalam memanfaatkan SHM sebagai agunan.

Kemungkinan lain penyebab masih rendahnya pemanfaatan sertifikat sebagai jaminan kredit pada penelitian ini terkait dengan tipologi daerah penelitian di Desa Banjaroya dan sekitarnya. Berdasarkan observasi dilapangan daerah penelitian merupakan daerah perbukitan/punggung gunung, yang kurang subur. Usaha di bidang pertanian yang merupakan mata pencaharian pokok mereka selain sebagai peternak merupakan pertanian dengan air irigasi yang terbatas, cenderung tadah hujan atau merupakan pertanian lahan kering. Keberhasilan usaha dibidang pertanian sangat dipengaruhi oleh tingkat kesuburan tanah suatu daerah dan faktor alam. Hal ini sedikit banyak berpengaruh terhadap belum maksimalnya keinginan untuk mengembangkan usaha di bidang pertanian tersebut, sehingga menyebabkan keikutsertaan dalam program sertifikasi tanah tidak berpengaruh signifikan terhadap keputusan PMK dalam memanfaatkan SHM sebagai jaminan kredit.

Dampak ekonomi pendaftaran tanah di Kabupaten Sleman, Malang, dan Kabupaten Banyumas berdasarkan empat tipologi wilayah. Hasil penelitian didapatkan bahwa untuk wilayah perkotaan sebagian besar 
pemilik sertifikat memanfaatkan untuk jaminan kredit (sebesar 70 persen), di wilayah semi kota ternyata malah sebaliknya hanya 15 persen saja yang menggunakan untuk jaminan kredit, untuk desa subur sudah 60 persen pemilik sertifikat memanfaatkannya sebagai jaminan kredit dan untuk desa kurang subur hanya 25 persen (sebagian kecil) yang menggunakan untuk jaminan kredit (Darmawan dan Santoso, 2002). Sertifikat tanah yang dihasilkan dari program sertifikasi tanah-tanah UMK yang tidak diagunkan ke bank untuk menambah permodalan, maka diindikasikan tidak berpengaruh terhadap sosial ekonomi masyarakat, walaupun nilai agunan tanahnya meningkat (Sidipurwanty, 2008). Pendaftaran tanah mempunyai dampak yang lemah terhadap kesadaran tentang hak atas tanah bagi petani dalam penggunaan kredit, hasil pertanian, dan konsentrasi hak milik tanah. Pendaftaran tanah lebih berpengaruh terhadap keamanan hak milik tanah daripada menaikkan produktivitas (Place dan Adholla, 1998). tingkat signifikansi masing-masing variabel independen. Apabila tingkat signifikansi variabel independen $<0,05$, maka variabel independen tersebut berpengaruh signifikan terhadap variabel dependennya pada level 5 persen, dan sebaliknya.

Kenaikanomzet usaha $\left(X_{1}\right)$ secara signifikan berpengaruh positif terhadap kenaikan jumlah pinjaman dari lembaga keuangan dalam hal ini koperasi. Jika omzet PMK tersebut mengalami kenaikan berarti volume penjualan atas barang/jasa yang diproduksi dalam kurun waktu tertentu mengalami kenaikan, sehingga pendapatan PMK tersebut juga naik yang pada akhirnya laba atau keuntungan yang diperolehnya juga mengalami kenaikan. Jadi kenaikan omzet kecenderungannya akan diikuti dengan kenaikan laba/keuntungan. Kenaikan omzet merupakan indikasi bahwa pertumbuahn ekonomi perusahaan tersebut sangat bagus sehingga pihak lembaga keuangan layak memberikan kenaikan jumlah pinjaman/kredit.

\section{Analisis Regresi Linear Berganda (Kenaikan Jumlah pinjaman yang diberikan lembaga keuangan kepada PMK selaku pemilik tanah/ $\mathrm{Y}_{2}$ )}

Tabel 3. Hasil Analisis Faktor-Faktor yang Mempengaruhi Kenaikan Jumlah Pinjaman dari Lembaga Keuangan $\left(Y_{2}\right)$

\begin{tabular}{|l|l|l|l|l|}
\hline No. & \multicolumn{1}{|c|}{ Variabel } & \multicolumn{1}{|c|}{ Koefisien } & $\begin{array}{c}\text { Prob } \\
(\mathbf{p} \text {-value })\end{array}$ & \multicolumn{1}{|c|}{ Keterangan } \\
\hline 1. & Konstanta & 4,0032 & 0,3118 & Tidak signifikan \\
\hline 2. & Kenaikan omzet $\left(\mathrm{X}_{1}\right)$ & 1,1525 & 0,0000 & Signifikan \\
\hline 3. & Penggunaan Sertifikat (diagunkan/tidak) $\left(\mathrm{D}_{1}\right)$ & 0,2036 & 0,8517 & Tidak signifikan \\
\hline 4. & Persepsi terhadap Analisis Kredit $\left(\mathrm{X}_{2}\right)$ & 0,3656 & 0,0004 & Signifikan \\
\hline 5. & Umur $\left(\mathrm{X}_{3}\right)$ & $-0,1525$ & 0,0025 & Signifikan \\
\hline 6. & Jenis Kelamin $\left(\mathrm{D}_{2}\right)$ & 0,2826 & 0,7837 & Tidak signifikan \\
\hline 7. & Tingkat pendidikan $\left(\mathrm{X}_{4}\right)$ & $-1,0054$ & 0.0511 & Tidak Signifikan \\
\hline 8. & Keikutsertaan progam $\left(\mathrm{D}_{3}\right)$ & 0,7448 & 0,8742 & Tidak signifikan \\
\hline
\end{tabular}

Persamaan regresi linear berganda sebagai berikut:

$$
\begin{aligned}
\mathrm{Y}= & 4,0032+1,1522 \mathrm{X}_{1}+0,2036 \mathrm{D}_{1}+ \\
& 0,3656 \mathrm{X}_{2}-0,1525 \mathrm{X}_{3}+0,2826 \mathrm{D}_{2}- \\
& 1,0054 \mathrm{X}_{4}+0,7448 \mathrm{D}_{3}+\epsilon_{\mathrm{i}}
\end{aligned}
$$

Tingkat Signifikansi ( $a$ ) yang digunakan sebesar 5 persen dan dibandingkan dengan
Penggunaan sertifikat tanah sebagai agunan $\left(D_{1}\right)$ tidak berpengaruh secara signifikan terhadap kenaikan jumlah pinjaman dari lembaga keuangan. Hal ini berarti penggunaan sertifikat sebagai agunan dalam penelitian ini tidak menjadi dasar pertimbangan pihak koperasi untuk menaikkan jumlah pinjaman. Hal ini 
disebabkan karena lokasi obyek tanah yang disertifikatkan sebagian besar berada di daerah perbukitan atau punggung gunung dengan pertanian lahan kering yang agak tandus dan tadah hujan. Walaupun tanah sudah bersertifikat dan mempunyai kekuatan hukum yang jelas orang malas dan enggan untuk berinvestasi di daerah tersebut sehingga harga jual tanahnya tidak mengalami kenaikan atau nilai agunannya relatif tetap dan tidak mengalami kenaikan yang mencolok, sebagaimana yang dikatakan Sidipurwanty (2008) sertifikasi tanah-tanah UMK dapat meningkatkan nilai agunan tanah sebesar 100 persen sampai dengan 400 persen.

Dampak program sertifikasi masal terhadap penyerapan modal dalam menunjang pengembangan UKM di Kota Cimahi, ternyata program sertifikasi massal di Kota Cimahi belum memberikan dampak berarti bagi peningkatan pinjaman UKM atau penyerapan modal UKM (Abdullatief ,2005 dan Amir, 2008). Persepsi PMK terhadap analisis kredit yang diterapkan lembaga keuangan $\left(X_{2}\right)$ secara signifikan berpengaruh positif terhadap kenaikan jumlah pinjaman darilembaga keuangan. Hasil analisistersebut dapat menggambarkan performan debitur, terutama kondisi dan pertumbuhan usaha debitur sehingga didapatkan debitur yang benar-benar layak untuk diberikan kredit karena mampu dan sanggup membayar dan melunasi pinjaman, sehingga dapat dicegah secara dini kemungkinan terjadinya default atau kegagalan nasabah dalam memenuhi kewajibannya untuk melunasi kredit yang diterimanya beserta bunga yang telah disepakati dan sudah diperjanjikan bersama.

Umur responden $\left(X_{3}\right)$ berpengaruh signifikan terhadap kenaikan jumlah pinjaman lembaga keuangan. Umur menjadi salah satu dasar pertimbangan koperasi sebagai lembaga keuangan dalam penelitian ini untuk mengevaluasi kondisi usaha dan perilaku kewirausahaan pelaku UMK, terkait dengan keputusan dalam menaikkan jumlah pinjaman. Usia adalah sebuah faktor penentu dalam orientasi pertumbuhan. Hasil penelitian menunjukkan distribusi PMK baik peserta program dan bukan peserta lebih banyak pada usia 50 tahun keatas. Pada peserta program yang berumur 60 tahun keatas yang lebih mendominasi sebesar 38,89 persen, kemudian umur 50-59 tahun dan 40-49 tahun masing-masing sebesar 30,56 persen dan 25 persen. Hal ini terkait dengan pemenuhan persyaratan objek tanah dalam proses pendaftaran tanah.

Salah satu kriteria objek tanah adalah bukan merupakan tanah warisan yang belum dibagi karena tanah warisan yang belum dibagi harus mendapatkan persetujuan dari semua ahli waris dan biasanya kendalanya adalah sulitnya mendatangkan dan mendapatkan persetujuan tersebut. Pada umumnya tanah-tanah PMK di daerah penelitian masih merupakan tanah milik orang tua yang belum dipecah atau belum diturunkan kepada anak-anaknya sehingga tidak dapat diikutkan dalam program sertifikasi, walaupun mereka secara persyaratan subyek memenuhi dan punya keinginan besar untuk mengajukan pinjaman. Peserta program umumnya merupakan pemilik tanah dengan usia yang sudah tua yang cenderung mulai menurun produktivitasnya. Pada kisaran umur tersebut kecenderungan motivasi usaha dan semangat mengembangkan usaha sangat turun, apalagi biasanya anak-anak mereka sudah dapat mandiri dan berkeluarga sehingga tanggung jawab berkurang.

Tingkat pendidikan $\left(\mathrm{X}_{4}\right)$ secara signifikan tidak berpengaruh terhadap kenaikan jumlah pinjaman dari lembaga keuangan. Dalam usaha mikro dan kecil pada umumnya mempunyai pendidikan formal yang masih rendah, dengan usaha yang masih bersifat turun temurun dan masih menggunakan teknologi sederhana atau masih bersifat tradisional. Pendidikan informal lebih dibutuhkan oleh PMK dan akan lebih berpengaruh dalam mendukung kesuksesan usaha mereka. Kemampuan manajemen yang masih terbatas menjadi salah satu faktor utama kegagalan UMK selama ini. Perbaikan manajemen usaha melalui pendidikan informal seperti kursus-kursus, diklat, atau pelatihan-pelatihan singkat tentang tata kelola 
usaha, sangat efektif bagi peningkatan usaha. Walaupun pendidikan hanya SD apabila sering mengikuti pelatihan-pelatihan pengelolaan usaha pasti akan lebih berhasil dibandingkan dengan pendidikan yang lebih tinggi dengan kemampuan manajemen usahanya pas-pasan. Pendidikan informal sangat berpengaruh dalam keberhasilan wirausaha.

Keikutsertaan responden dalam program sertifikasi tanah UMK $\left(\mathrm{D}_{3}\right)$ tidak berpengaruh signifikanterhadapkenaikanjumlah pinjaman. Hal ini secara tidak langsung dikarenakan pemanfaatan sertifikat tanah sebagai jaminan kredit masih sangat rendah, belum menjadi motivasi utama dalam keikutsertaan PMK pada program sertifikasi tanah. Keikutsertaan dalam program sertifikasi belum berpengaruh maksimal dalam perkembangan usahanya, karena tidak serta merta mempengaruhi PMK dalam memanfaatkan SHM sebagai agunan. Hal ini secara tidak langsung menyebabkan keikutsertaan program sertifikasi tidak berpengaruh pada kenaikan jumlah pinjaman yang ditawarkan lembaga keuangan.

\section{SIMPULAN}

Berdasarkan hasil analisis penelitian Pengaruh Program Sertifikasi Tanah UMK tahun 2008 di Kabupaten Kulon Progo terhadap akses permodalan bagi UMK sebagai berikut: Pertama, faktor-faktor yang signifikan mempengaruhi keputusan PMK dalam memanfaatkan SHM sebagai jaminan kredit dalam penelitian ini adalah keinginan PMKdalampengembanganusaha, kesesuaian jumlah kredit yang diperoleh dan yang dibutuhkan, persepsi prosedur peminjaman, dan persepsi kemampuan membayar kredit PMK tersebut. Program Sertifikasi Tanah UMK tahun 2008 yang dilaksanakan di Kabupaten Kulon Progo belum memberikan dampak yang berarti terhadap peningkatan akses permodalan bagi UMK. Hal ini ditunjukkan dengan tidak signifikannya pengaruh variabel keikutsertaan PMK dalam program sertifikasi tanah terhadap keputusan dalam memanfaatkan SHM hasil program sertifikasi tanah tersebut sebagai jaminan kredit. Kedua, Program Sertifikasi
Tanah UMK tahun 2008 yang dilaksanakan di Kabupaten Kulon Progo belum mempunyai pengaruh yang signifikan terhadap peningkatan akses permodalan bagi PMK ditinjau dari aspek kenaikan jumlah pinjaman yang diberikan oleh lembaga keuangan kepada PMK selaku pemilik tanah. Faktorfaktor yang berpengaruh terhadap kenaikan jumlah pinjaman dari lembaga keuangan dalam penelitian ini adalah kenaikan omzet, persepsi UMK terhadap analisis yang diterapkan lembaga keuangan, umur, dan tingkat pendidikan PMK.

Tujuan Program Sertifikasi Tanah UMK selain pemberian kepastian hukum hak atas tanah bagi UMK, yaitu tujuan peningkatan akses terhadap sumber-sumber permodalan bagi PMK tercapai, dalam pemilihan subjek program sertifikasi tanah sebaiknya diperhatikan juga aspek kelayakan usaha dan faktor-faktor lain yang berpengaruh dalam pengembangan usaha bagi PMK baik faktor internal maupun eksternal, antara lain usia, tingkat pendidikan yang terkait dengan kemampuan manajerial, lokasi, dan jenis usaha. Manfaat SHM hasil Program Sertifikasi Tanah UMK selain meningkat legalitas diharapkan dapat meningkat akses permodalan sehingga berdampak pada pengembangan UMK.

Program Sertifikasi Tanah UMK agar dapat berpengaruh terhadap kenaikan jumlah pinjaman yang ditawarkan lembaga keuangan pada PMK selaku pemilik tanah, dalam pelaksanaannya selain mengutamakan ketepatan dalam pemilihan subyek dan obyek penerima program baik dari aspek persyaratan legalisasi asset maupun kelayakan usaha, perlu dilakukan juga pembinaan terhadap tata kelola usaha sehingga menunjang pengembangan UMK. Oleh karena itu, perlu ditingkatkan koordinasi yang baik antara instansi-instansi terkait yaitu BPN RI, Kementerian Koperasi dan UKM, Pihak lembaga keuangan/ perbankan/koperasi dan instansi terkait lain, sehingga program benar-benar memberikan dampak yang berarti dalam menunjang kesejahteraan UMK. 


\section{DAFTAR PUSTAKA}

Amir, A, 2008, “Analisis Dampak Program Sertipikasi Tanah Terhadap Akses Kredit Perbankan dan Peningkatan Pendapatan Petani di Kabupaten Bekasi" Tesis S2, Magister Studi Manajemen dan Bisnis, Sekolah Pascasarjana, Institut Pertanian Bogor.

Arsyad, L, 1999, Pengantar Perencanaan dan Pembangunan Ekonomi Daerah. Edisi Pertama, BPFE, Yogyakarta.

Boediono, 2008, Ekonomi Mikro: Seri Sinopsis Pengantar Ilmu Ekonomi No. 1. Edisi 2, BPFE, Yogyakarta.

Byamugisha, F.F.K., 1999, Policy Research Working Paper: The Effects of Land Registration on Financial Development and Economic Growth : A Theoretical and conceptual Framework, World Bank Policy Research Working Paper 2240.

Darmawan, D.A, 2001, “Kajian Teoritis Dampak Pendaftaran Tanah Terhadap Pengembangan Ekonomi Wilayah" Jurnal IPTEK Pertanahan Vol. 1 No. 7 Juli 2001.

Darmawan, D.A, dan Santoso, J, 2001, "Dampak Ekonomi Pendaftaran Tanah". Jurnal IPTEK Pertanahan.

Fahmi, I, dan Hadi, Y.L., 2009, Pengantar Manajemen Perkreditan, Alfa Beta, Bandung.

Hutagalung, R.B., dan Situmorang, S. H, 2008, Pengantar Kewirausahaan. USU Press, Medan.

Jumhur, 2006, “Analisis Permintaan Kredit Modal Kerja Usaha Kecil Di Kota Semarang (Studi Kasus Permintaan Modal Kerja Usaha Kecil Sektor Perdagangan dari BMT)" Tesis S2, Magister Ilmu Ekonomi dan Studi Pembangunan, Program Pascasarjana Universitas Diponegoro Semarang.
Kasmir, 2003, “Manajemen Perbankan” PT. Raja Grafindo Persada, Jakarta.

Kuncoro, M, 2009, Ekonomika Indonesia: Dinamika Lingkungan Bisnis di Tengah Krisis Global, UPP STIM YKPN, Yogyakarta.

Mesman, A, 2008, “Analisis Pengaruh Sertipikat Hak Atas Tanah Terhadap Kinerja Ekonomi Pengusaha Mikro dan Kecil di Kabupaten Konawe Selatan". Tesis S2. Magister Studi Manajemen dan Bisnis, Sekolah Pascasarjana, Institut Pertanian Bogor.

Noersasongko, E, 2005, “Analisis Pengaruh KarakteristikIndividu,Kewirausahaan dan Gaya Kepemimpinan Terhadap Kemampuan Usaha Serta Keberhasilan Usaha Pada Usaha Kecil Batik di Jawa Tengah". Disertasi, Program Pascasarjana Universitas Merdeka Malang.

Panggabean, R, 2008, Kerjasama Bank, Koperasi dan Lembaga Keuangan Mikro (LKM) Mendukung Pemberdayaan Usaha Mikro Kecil dan Menengah (UMKM), Peneliti pada Deputi Bidang Pengkajian Sumber Daya UKMK. Kementerian Negara Koperasi dan UKM, Jakarta.

Pasaribu, F, 2007, "Hubungan Karakteristik Pegawai Dengan Produktivitas Kerja" Jurnal Ichsan Gorontalo Volume 2, No. 1, Februari - April 2007.

Place, Frank dan Adholla, Migot, S.E, 1998, "The Economic Effects of Land Regrsitration on Smallholder Farms in Kenya: Evidence from Nyeri and Kakamega Districts". Jurnal Land Economics, The University of Wisconsin Press. Volume 74, No. 3, pp. 360-373, August 1998.

Ridwan, 2010, “Peta Ekonomi Usaha Mikro, Kecil dan Menengah (UMKM) di Kabupaten Kulon Progo Daerah Istimewa Yogyakarta". EFEKTIF 
Jurnal Bisnis dan Ekonomi Vol. I, No. 1, Juni 2010, 1-15, Fakultas Ekonomi Universitas Janabadra.

Sidipurwanty, E, 2008, "Sertifikasi TanahTanah Usaha Mikro dan Kecil (Kendala dan Dampaknya)" Jurnal Iptek Pertanahan Vol. VIII Nomor 1, Tahun 2008.

Subandi, S. 2007, Potensi Pengembangan Permodalan UMKM Dari Pinjaman Perbankan. Artikel. Diakses dari: http://www.smecda.com/deputi7/ file Infokop/VOL1502/5\%20 slamet-2.pdf, pada tanggal 9 Juli 2012.

Suhardjono, 2003, Manajemen Perkreditan Usaha Kecil dan Menengah. UPP AMP YKPN, Yogyakarta.

Sulaeman, S, 2004, Pengembangan Usaha Kecil dan Menengah Dalam Menghadapi Pasar Regional dan Global, Infokop Nomor 25 Tahun XX.

Winarno, W.W., 2007, Analisis Ekonometri dan Statistika dengan Eviews, UPP STIM YKPN, Yogyakarta.; 